\title{
Liver Organ Impairment Due to the Consumption of Kratom Leaves (Mitragyna speciosa Korth.)
}

\author{
Ruqiah Ganda Putri Panjaitan*, Linda Liridah
}

\section{Ruqiah Ganda Putri Panjaitan*, Linda Liridah}

Department of Biology Education, Faculty of Teacher Training and Education, Tanjungpura University. Jl. Prof. Dr. $\mathrm{H}$. Hadari Nawawi, Bansir Laut, Kec. Pontianak Tenggara, Kota Pontianak, West Kalimantan 78124, INDONESIA.

\section{Correspondence}

Ruqiah Ganda Putri Panjaitan

Department of Biology Education, Faculty of Teacher Training and Education, Tanjungpura University. JI. Prof. Dr. H. Hadari Nawawi, Bansir Laut, Kec. Pontianak Tenggara, Kota Pontianak, West Kalimantan 78124, INDONESIA

E-mail: ruqiah.gpp@fkip.untan.ac.id

\section{History}

- Submission Date: 23-10-2020;

- Review completed: 15-11-2020;

- Accepted Date: 25-11-2020.

DOI : 10.5530/pj.2021.13.25

Article Available online

http://www.phcogj.com/v13/i1

\section{Copyright}

(C) 2021 Phcogj.Com. This is an openaccess article distributed under the term of the Creative Commons Attribution 4.0 International license.

\section{ABSTRACT}

This study was aimed to evaluate the administration effects of kratom leaves extracts on the liver of mice (Mus musculus). The total of 25 mice was divided into five groups, respectively; (A) without treatment, (B) treatment with distilled water at $0.50 \mathrm{ml} / 20 \mathrm{~g}$ body weight, (C) treatment of kratom leaves extracts with a dosage of $0.15 \mathrm{mg} / 20 \mathrm{~g}$ body weight, (D) treatment of kratom leaves extracts with a dosage to $0.30 \mathrm{mg} / 20 \mathrm{~g}$ body weight and (E) treatment with a dosage of silymarin at $0.70 \mathrm{mg} / 20 \mathrm{~g}$ body weight. All those treatments were completed in seven consecutive days. On day 8 , blood withdrawal and liver dissection were executed. The average levels of AST enzyme in the treatment groups respectively showed $22.81 \mathrm{U} / \mathrm{L}(\mathrm{A})$, 23.30 U/L (B), $34.86 \mathrm{U} / \mathrm{L}(\mathrm{C}), 40.68 \mathrm{U} / \mathrm{L}(\mathrm{D})$, and 25.44 U/L (E), $(\mathrm{p}<0.05)$. Whereas, the average levels of $A L T$ exposed respectively at $17.96 \mathrm{U} / \mathrm{L}(\mathrm{A}), 18.35 \mathrm{U} / \mathrm{L}(\mathrm{B}), 29.13 \mathrm{U} / \mathrm{L}(\mathrm{C}), 33.59 \mathrm{U} / \mathrm{L}(\mathrm{D})$, and $20.68 \mathrm{U} / \mathrm{L}(\mathrm{E}),(\mathrm{p}<0.05)$. The average scoring for the treatment groups resulted in 0.33 , $0.67,1.33,1.67$, and 0.67 , respectively, with $p<0.05$. Hence, it was concluded that the higher doses of the extracts of kratom leaves administered during the treatment, the more severe damage the liver organ became.

Key words: ALT, AST, Kratom leaves, Liver organ.

\section{INTRODUCTION}

Kratom (Mitragyna speciosa Korth) is one of the plant types widely growing in African and Southeast Asia $^{1,2}$, as well as in the territory of the Pacific Islands. ${ }^{1}$ In Southeast Asia, kratom is mainly found in the territory lands of Thailand and Malaysia $^{3,4}$, including Indonesia. ${ }^{4}$ This plant has its unique names in each area, for instance, kratom in the region of Thailand, biak-biak in the region of Malaysia ${ }^{5}$, while purik in the territory of Indonesia, especially in Kabupaten Kapuas Hulu called by the local people. Kratom is a type of woody plant with a height of up to 15-20 meters.

Traditionally, people in Malaysia, Thailand, and Southeast Asia utilise kratom leaves as a botanical medicine for a drug of diarrhoea, diabetes, and blood circulation. ${ }^{6}$ In addition, Gong et al. ${ }^{7}$ also reported that the kratom leaves are beneficial to treat fever, malaria, diarrhoea, muscle pain, inflammation, and hypertension. In Indonesia, traditionally, kratom leaves are used to cure diarrhoea, muscle pain, lower blood pressure, as well as a stamina booster.

The results of previous studies showed that the main compounds contained in kratom leaves are the classes of alkaloids, i.e., mitragynine. ${ }^{2,8-13}$ According to Lesiak et al. ${ }^{14}$ mitragynine has also been revealed in other plants. Furthermore, if compared to Mitragyna rotundifolia, mitragynine is only detectable in the leaves of Mitragyna speciosa Korth. ${ }^{15}$ Mitragynine is also suggested to have properties such as opioids ${ }^{16-18}$; correspondingly Carpenter et al. ${ }^{19}$ also revealed that mitragynine has the activity of antinociceptive. However, excessive administration of mitragynine may increase locomotor activities spontaneously; thus, it could potentially promote a drug-induced property of kratom leaves, which even resulted in the severity of side effects of opioids. ${ }^{20,21}$ Besides, Abdullah et al. ${ }^{22}$ also demonstrated that kratom has a stimulant property as a psychoactive herb even in a low dose; on the contrary, it will have such opioids effects when consumed at higher doses. Moreover, the abuse use of kratom also may cause poisoning and drug withdrawal symptoms. ${ }^{23}$ In line with that, Osborne et al. ${ }^{24}$ disclosed that a 47-year-old person was diagnosed with drug-induced liver injury (DILI) after consuming kratom for 21 consecutive days.

Various results of previous studies demonstrated that the medicines belonging to the class of opioids are codeine ${ }^{25}$ and paracetamol ${ }^{26}$. These drugs will undertake metabolism in the body. Specifically, paracetamol undergoes metabolism through the process of glucuronidase, sulfatase, and oxidation by isoenzymes of the cytochrome P-450, which take place in the heart, then will be excreted through the kidneys. The process of oxidation by isoenzymes of the cytochrome P-450 will alter the paracetamol into $N$-acetyl-p benzoquinone-imine (NAPQI)..$^{27,28}$ Not only paracetamol, but does codeine also belong to the class of opioid drugs, which undergoes the same process of metabolism in the liver. The presence of the enzyme CYP2D6 mainly plays a role in the codeine alteration into its active form of morphine. Polymorphism in the gene CYP2D6 affects the metabolic activity of the enzymes coded. The polymorphism in CYP2D6 generated four types of metabolism, i.e., extensive metabolizer (EM), intermediate metabolizer (IM), poor metabolizer (PM), and ultra-rapid metabolizer (UM) ${ }^{25}$ 
Liver is one of the responsible organs, which has an essential function in the metabolism of drugs. ${ }^{29,30}$ Also, liver plays a role in the metabolism of carbohydrates, protein, and fat. ${ }^{29,31}$ Liver belongs to the organ system of a body which is vital in the setting of a variety of physiological processes and is closely related to the metabolism of nutrients and xenobiotics that are primarily exposed to any hazardous substances entering the body. ${ }^{32-}$ ${ }^{36}$ Damage on the liver will undoubtedly affect the function of the liver itself. This damage is characterized by the presence of increased enzyme levels of alanine transaminase (ALT) and aspartate transaminase (AST) in blood serum. ${ }^{32,33,37}$ Besides, the liver damage is also identified by the increased levels of alkaline phosphatase (ALP), total bilirubin, and total protein in blood serum. ${ }^{38}$

Correspondingly, the utilization of kratom leaves for the community and the possibility of the negative impact caused by the consumption of kratom leaves, including information about the liver organ that plays a role in the metabolism of drugs, this study was aimed to determine the effects of the extract of kratom leaves against the liver organ.

\section{MATERIAL AND METHODS}

\section{Collection of plant materials}

Fresh kratom leaves were collected from the garden community in the area of the Village of Nanga Nyabau, North Putussibau Subdistrict, Kapuas Hulu Regency, West Kalimantan Province. The identification of the authentic plants was performed and declared by the Laboratory of Biology, Faculty of Mathematics and Natural Sciences, Tanjungpura University with a letter numbered 045/A/LB/FMIPA/UNTAN/2018.

\section{Experimental animals}

Experimental animals used in this study were male mice of the strain $\mathrm{Balb} / \mathrm{C}$, aged 2-3 months with the bodyweight ranging between 24-36 grams. All trial animals were collected from the Laboratory Centre of Food and Nutrition Studies, Gadjah Mada University, Yogyakarta, Indonesia. Experimental animals were placed in the acclimatization for 14 days before treatments. During acclimatization, the experimental animals were fed with standard feed, drank ad libitum, and were observed their health through weighing the bodyweights. The whole procedure associated with the maintenance and treatment of the experimental animals has already met the ethical requirements stated by the Commission of Ethics of Animals, University of Respati Yogyakarta on the letter numbered 217.2/UNRIYO/PL/IX/2018.

\section{Extraction}

The dried leaves of $285 \mathrm{~g}$ were extracted by using the solvent of distilled ethanol $96 \%$. Samples were then immersed at room temperature for 24 hours. The immersion was done three times by adding new ethanol at each repetition. After that, the filtrate was then concentrated by using a vacuum rotary evaporator. The obtained extracts were a total of $19.01 \mathrm{~g}$ with a submerged yield of $6.67 \%$. The extraction process was implemented, referring to the Harborne method. ${ }^{39}$

\section{The Administration Effect of The Extracts of Kratom Leaves on The Liver of Mice}

A total of 25 mice were divided into five groups, with each group of 5. Group A was the group without treatment (control group). Group $B$ received distilled water of $0.50 \mathrm{ml} / 20 \mathrm{~g}$ body weight. Group C was treated with the extracts of kratom leaves with a dosage of $0.15 \mathrm{mg} / 20$ g body weight. Group D received the extracts of kratom leaves with a dosage of $0.30 \mathrm{mg} / 20 \mathrm{~g}$ body weight. At the same time, group $\mathrm{E}$ was executed with the administration of silymarin at $0.70 \mathrm{mg} / 20 \mathrm{~g}$ body weight. Treatments were given for seven consecutive days; on the 8th day, it continued for withdrawing blood samples and removing the liver organ. The measured parameters were the enzyme levels of aspartate transaminase (AST) and alanine transaminase (ALT) in blood serum, as well as an overview of the histopathological series of the dissection liver organ.

\section{Blood biochemical examination}

Blood samples were drawn from the orbital sinus. The obtained blood collections were then centrifuged at $4000 \mathrm{rpm}$ for 15 minutes. Then the serum was separated and put into eppendorf tubes. Subsequently, the measurement of the enzyme levels of alanine transaminase (ALT) and aspartate transaminase (AST) was performed using a kit of DiaSys (Diagnostic System) by the UV-Test method.

\section{Liver histopathology}

The animals were sacrificed through cervical dislocation. The removed livers were then processed routinely, for staining with haematoxylineosin (HE).$^{40}$ The overview of the liver histopathology was observed under a light microscope, and changes appeared were scored (Table 1).

\section{Data analysis}

This study was conducted using a completely randomized design. Data on blood levels of ALT, AST, and liver scoring were statistically analysed by using SPSS 20, following the test of Duncan at level 5\%.

\section{RESULTS AND DISCUSSION}

Indonesia has a diversity of plant species, which is traditionally used in folk medicine. Treatment by utilizing medicinal plants is widely performed because it is relatively easy to find, and the cost incurred to acquire it is also relatively cheap. More than that, people believe that the side effects of plant drugs compared to synthetic ones are relatively low. Nevertheless, the usage of plants in disease treatments still requires the accuracy of the doses used and the period consumption. Due to excessive usage, it is not likely to cause serious health problems.

Kratom is an herbal remedy that originates from Southeast Asia that has the main compound in the form of mitragynine., , $910,11-13$ Mitragynine in pharmacological view specifies the presence of medicinal properties such as opioids. ${ }^{41,42}$ Smith et al ${ }^{42}$ reported that communities in Southeast Asian countries, such as Malaysia and Thailand, have been long using kratom leaves by chewing, smoking, or brewing into a tea. Even by the people of villages in the region of Southern Thailand, kratom leaves are used to treat coughs, diarrhoea, muscle pain, and hypertension. ${ }^{43,44}$ Scientifically, it was reported that kratom could function as a stimulant if administered at low doses; on the contrary, it might potentially lead to a sedative effect, analgesic, and euphoria if given at high doses. ${ }^{41,45}$ Research conducted by Halpenny ${ }^{46}$ and Yusoff et al.$^{47}$ also exhibited that the administration of mitragynine could trigger someone to become addicted, hence kratom may potentially become a dangerous drug.

The consumption of kratom leaves will accordingly result after drinking its decoction. The decoction water of the kratom leaves will enter and go into the digestive tract, then be absorbed by the intestines. After that, these materials will undergo the process of metabolism in the liver. Due to the frequent exposure to a wide variety of materials that enter the body, this undoubtedly provokes the liver to be the most susceptible organ to damage. . $^{32,33,38,48}$ The current study was performed to evaluate the condition of the liver due to consuming kratom leaves, and the results of this finding were presented in Table 2, Table 3, and Figure 1.

Blood contains various substances that can provide a scientifically thorough explanation for the physiological condition of an individual. ${ }^{35}$ One of the substances containing in the blood is an enzyme, and enzyme levels in the blood may suggest an indicator of the health state on individuals. The enzyme level of AST and ALT is a parameter function of the liver that is the most sensitive factor because changes in levels will quickly indicate a specific state if there is damage to liver cells. ${ }^{32,34,36,37,38,48}$ 


\section{Table 1: Scoring degree of liver damage.}

\begin{tabular}{cl}
\hline Score & Description \\
\hline 0 & Not found specific changes \\
1 & Liver cells underwent hydropic and fatty degeneration in low degree evenly \\
2 & The liver cells underwent fatty degeneration and steatosis in medium degree, which was multifocal. \\
3 & The liver cells underwent fatty degeneration, steatosis, and dystrophy in severe degree, which was multifocal. \\
\hline
\end{tabular}

Table 2: The average enzyme levels of the alanine transaminase (ALT) and aspartate transaminase (AST) in mice administered with the extracts of kratom leaves for seven consecutive days.

\begin{tabular}{ccc}
\hline Treatment Groups & \multicolumn{2}{c}{ The Average Enzyme Levels } \\
\cline { 2 - 3 } Without Treatment & AST (U/L) & $17.96 \pm 0.34^{\mathrm{a}}$ \\
\hline Distilled water of $0.50 \mathrm{ml} / 20 \mathrm{~g}$ body weight & $22.81 \pm 0.49^{\mathrm{a}}$ & $18.35 \pm 0.41^{\mathrm{a}}$ \\
Extracts of kratom leaves at $0.15 \mathrm{mg} / 20 \mathrm{~g}$ body weight & $23.30 \pm 0.34^{\mathrm{a}}$ & $29.13 \pm 0.34^{\mathrm{c}}$ \\
Extracts of kratom leaves at $0.29 \mathrm{mg} / 20 \mathrm{~g}$ body weight & $34.86 \pm 0.93^{\mathrm{c}}$ & $33.59 \pm 0.43^{\mathrm{d}}$ \\
Silymarin at $0.70 \mathrm{mg} / 20 \mathrm{~g}$ body weight & $40.68 \pm 0.59^{\mathrm{d}}$ & $20.68 \pm 0.95^{\mathrm{b}}$ \\
\hline
\end{tabular}

Description:

*) The same letters in the same column indicated not significantly different $(p>0.05)$

${ }^{* *}$ ) The numbers listed after the symbol \pm indicated the standard deviation (SD)

Table 3: Histopathological scoring of the liver of mice.

\begin{tabular}{cc}
\hline Treatment Groups & Scoring \\
\hline Without treatment & $0.33 \pm 0.58^{\mathrm{a}}$ \\
Distilled dose of $0.50 \mathrm{ml} / 20 \mathrm{~g}$ body weight & $0.67 \pm 0.58^{\mathrm{ab}}$ \\
Extract of kratom leaves at $0.15 \mathrm{mg} / 20 \mathrm{~g}$ body weight & $1.33 \pm 0.58^{\mathrm{ab}}$ \\
Extract of kratom leaves at $0.30 \mathrm{mg} / 20 \mathrm{~g}$ body weight & $1.67 \pm 0.58^{\mathrm{b}}$ \\
Silymarin dose of $0.70 \mathrm{mg} / 20 \mathrm{~g}$ body weight & $0.67 \pm 0.58^{\mathrm{ab}}$ \\
\hline
\end{tabular}

*) The same letters in the same column indicated not significantly different ( $\mathrm{p}>0.05)$

${ }^{* *}$ ) The numbers listed after the symbol \pm indicated the standard deviation (SD)

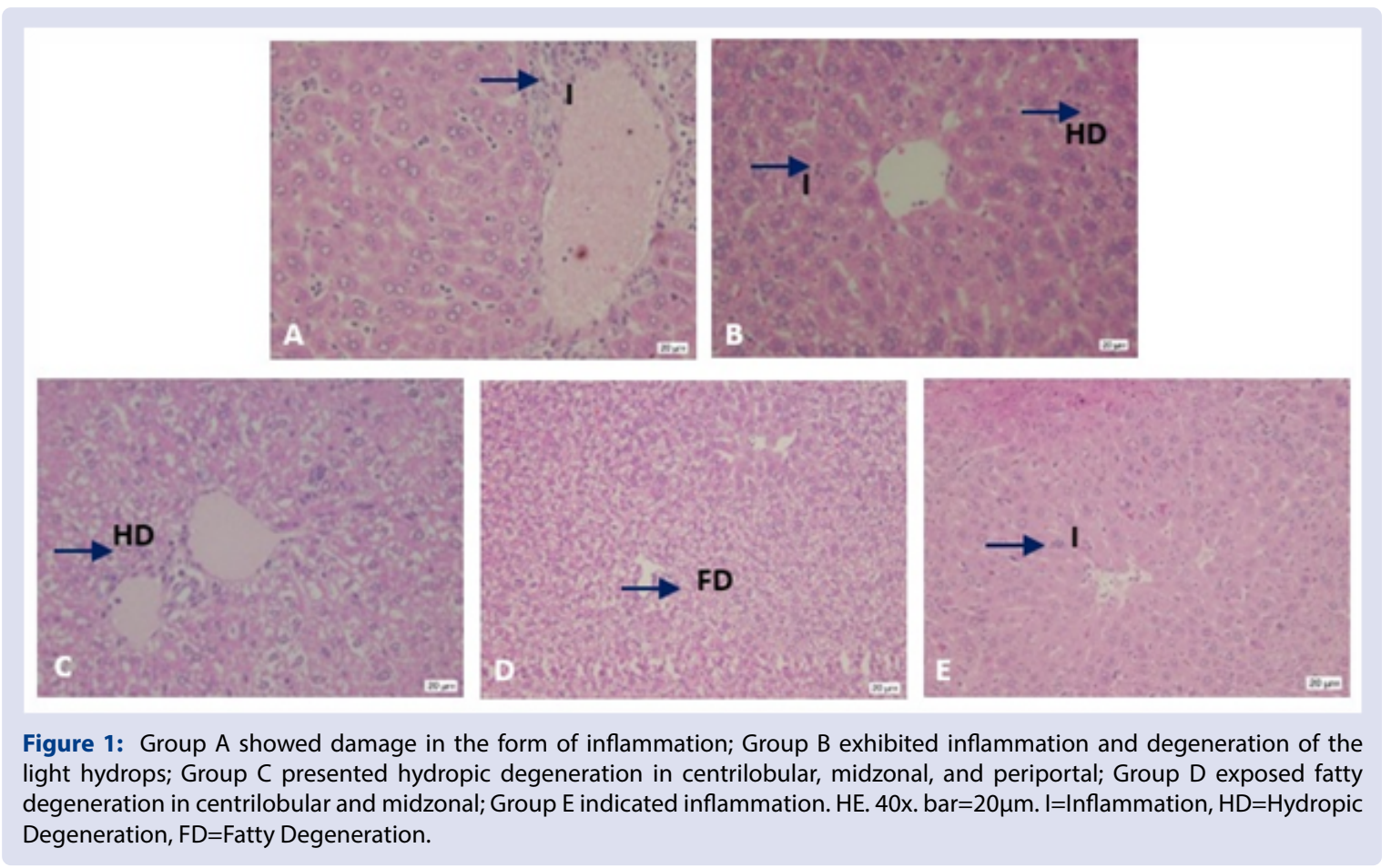


From the results of this study, it was displayed an overview of the levels of AST and ALT enzymes (Table 2), including the images shown from histopathological liver assessment (Figure1. and Table 3). This result was sufficiently meaningful on the administration of kratom leaves extracts where the increased levels of ALT and AST enzymes occurred, and this increase indicated the presence of damage to the liver cells. In line with the results of this study, Buraimoh et al. ${ }^{32}$ and Domitrović et al. ${ }^{33}$ expressed that the elevated levels of liver enzymes in the blood suggested that the liver experienced damage in a certain degree which was characterized by histopathological assessment in terms with the presence of lesions, degeneration, necrosis, and steatosis.

Overall, the results of this study revealed that the average levels of the ALT and AST enzymes and the histopathological overview of the liver of mice in the group without treatment and distilled water were relatively close to the group treated with silymarin; despite statistically the average levels of ALT and AST and scoring of the liver showed significantly different $(\mathrm{p}<0.05)$. On the other hand, the group of silymarin compared to the group administered by the kratom leaves extract, which showed the presence of improvement, was quite high on average levels of ALT and AST enzymes as well as the changes that appeared on the histopathological images. Likewise, the results of this study demonstrated that the higher the dose of kratom extracts given then the higher the average levels of ALT and AST enzymes, and the broader changes occurred on histopathological images.

Silymarin is a compound of the flavonoid groups found in fruits of the plant Silybum marianum. ${ }^{49}$ Silybum marianum is a medicinal plant with efficacy as a hepatoprotective. ${ }^{48,50}$ Silymarin is reported to have such antioxidant effects ${ }^{51,52}$, also anti-inflammatory and immunomodulatory effects. ${ }^{52}$ One of the previous researches on the effects of silymarin in patients with non-alcoholic fatty liver disease (NAFLD) also exhibited the ability improvement of the level of enzymes in the liver and insulin resistance..$^{53}$

The results of several previous studies revealed that the occurrence of fatty degeneration might be caused by a component in the alkaloidderived doses of a sample test. ${ }^{54}$ Correspondingly, mitragynine is an alkaloid metabolite contained in kratom. ${ }^{6,44}$ In addition to mitragynine, Ponglux et al. ${ }^{12}$ reported that in the leaves of the kratom are also contained $7 \alpha$-hydroxy- $7 H$-mitragynine, paynantheine, speciogynine, and speciociliatine. Moreover, other compounds are also confined in the kratom leaves such as ajmalicine, corynantheidine, isomitraphylline, mitraphylline, and isocorynantheidine, as well as the flavonoids epicatechin, daucosterol saponins, triterpenoid saponins quinovic acid 3-O- $\beta$-D-quinovopyranoside and quinovic acid 3-O- $\beta$ D-glucopyranoside, including some derivatives from a group of glycosides such as 1-O-feruloyl- $\beta$-D-glucopyranoside, benzyl- $\beta$-Dglucopyranoside, 3-oxo- $\alpha$-ionyl-O- $\beta$-D-glucopyranoside, roseoside, vogeloside, and epivogeloside..$^{13}$ Similarly, with regards to the content contained in kratom leaves, Prozialeck et al ${ }^{55}$ stated that the usage of kratom leaves on a long-term basis with large doses might trigger sedative effects, emotional disturbances, weight loss, kidney disorders, and addiction. Nevertheless, Raini ${ }^{56}$ reported that the effects of kratom would depend on the dose amounts administered; in lower doses, it may have a stimulatory effect, yet in higher doses, it may cause a mild narcotic effect, but not the strong one. The higher the doses of kratom leaves administered in a specific period during treatments, the more severe the damage in the liver developed.

\section{ACKNOWLEDGEMENT}

Our big appreciation to the community in the Village of Nanga Nyabau, North Putussibau Subdistrict, Kapuas Hulu Regency, West Kalimantan Province, which has helped us in the provision of kratom leaves.

\section{REFERENCES}

1. Smid MC, Charles JE, Gordon AJ, Wright TE. Use of kratom, an pioid-like traditional herb, in pregnancy. Obstet Gynecol. 2018;132(4):926-8.

2. Warner ML, Kaufman NC, Grundmann O. The pharmacology and toxicology of kratom: from traditional herb to drug of abuse. Int J Legal Med. 2016;130(1):12738.

3. Singh D, Narayanan S, Müller CP, Swogger MT, Chear NJY, Dzulkapli E Bin, et al. Motives for using kratom (Mitragyna speciosa Korth.) among regular users in Malaysia. J Ethnopharmacol. 2019;233:34-40.

4. Hauck ZZ, Nosal D, Breemen R. Quantitation of major indole and oxindole alkaloids from different kratom (Mitragyna speciosa) strain extracts using UHPLC-MS/MS. Planta Med. 2015;81(11).

5. Kong WM, Chik Z, Ramachandra M, Subramaniam U, Raja Aziddin RE, Mohamed Z. Evaluation of the effects of Mitragyna speciosa alkaloid extract on cytochrome P450 enzymes using a high throughput assay. Molecules. 2011;16(9):7344-56.

6. Idayu NF, Hidayat MT, Moklas MAM, Sharida F, Raudzah ARN, Shamima AR et al. Phytomedicine Antidepressant-like effect of mitragynine isolated from Mitragyna speciosa Korth in mice model of depression. Phytomedicine. 2011;18:402-7.

7. Gong F, Gu H, Xu Q, Kang W. Genus Mitragyna: Ethnomedicinal uses and pharmacological studies. Phytopharmacology. 2012;3(2):263-72.

8. Saidin NA, Gooderham NJ. In vitro toxicology of extract of Mitragyna speciosa Korth, a malaysian phyto-pharmaceutical of abuse. Toxicology. 2007;240:166-7.

9. Parthasarathy $S$, Ramanathan $S$, Murugaiyah $V$, Hamdan MR, Mohd Said MI Lai CS, et al. A simple HPLC-DAD method for the detection and quantification of psychotropic mitragynine in Mitragyna speciosa (ketum) and its products for the application in forensic investigation. Forensic Sci Int. 2013;226:183-7.

10. Hassan Z, Muzaimi M, Navaratnam V, Yusoff NHM, Suhaimi FW, Vadivelu $\mathrm{R}$, et al. From kratom to mitragynine and its derivatives: Physiological and behavioural effects related to use, abuse, and addiction. Neurosci Biobehav Rev. 2013;37:138-51.

11. Tanguay P. Kratom in Thailand: Decriminalisation and Community Control? Legislative Reform of Drug Policies. London: International Drug Policy Consortium; 2011. p. 16.

12. Ponglux D, Wongseripipatana S, Takayama $H$, Kikuchi $M$, Kurihara M, Kitajima $\mathrm{M}$, et al. A new indole alkaloid, 7 $\alpha$-hydroxy-7H-mitragynine, from Mitragyna speciosa in Thailand. Planta Med. 1994;60:580-1.

13. León F, Habib E, Adkins JE, Furr EB, McCurdy CR, Cutler SJ. Phytochemical characterization of the leaves of Mitragyna speciosa grown in USA. Nat Prod Commun. 2009;4(7):907-10.

14. Lesiak AD, Cody RB, Dane AJ, Musah RA. Rapid detection by direct analysis in real time-mass spectrometry (DART-MS) of psychoactive plant drugs of abuse: The case of Mitragyna speciosa aka "Kratom." Forensic Sci Int. 2014;242:210-8.

15. Sanagi MM, Ayob MFM, Omar N, Ibrahim WAW, Hussain I. Determination of mitragynine for the identification of Mitragyna species in kedah (malaysia) by gas chromatography-mass spectrometry. Der Pharma Chem. 2013;5(5):131-8.

16. Suhaimi FW, Yusoff NHM, Hassan R, Mansor SM, Navaratnam V, Müller CP, et al. Neurobiology of kratom and its main alkaloid mitragynine. Brain Res Bull [Internet]. 2016;126:29-40.

17. Takayama $\mathrm{H}$, Ishikawa $\mathrm{H}$, Kurihara $\mathrm{M}$, Kitajima $\mathrm{M}$, Aimi $\mathrm{N}$, Ponglux $\mathrm{D}$, et al. Studies on the synthesis and opioid agonistic activities of mitragynine-related indole alkaloids: Discovery of opioid agonists structurally different from other opioid ligands. J Med Chem. 2002;45(9):1949-56.

18. Thongpradichote S, Matsumoto K, Tohda M, Takayama H, Aimi N, Sakai SI, et al. Identification of opioid receptor subtypes in antinociceptive actions of supraspinally-administered mitragynine in mice. Life Sci. 1998;62(16):1371-8.

19. Carpenter JM, Criddle CA, Craig HK, Ali Z, Zhang Z, Khan IA, et al. Comparative effects of Mitragyna speciosa extract, mitragynine, and opioid agonists on thermal nociception in rats. Fitoterapia. 2016;109:87-90.

20. Saref A, Suraya S, Singh D, Grundmann O, Narayanan S, Swogger MT, et al Self-reported prevalence and severity of opioid and kratom (Mitragyna speciosa Korth.) side effects. J Ethnopharmacol. 2019;238:1-8.

21. Ismail NIW, Jayabalan N, Mansor SM, Müller CP, Muzaimi M. Chronic mitragynine (kratom) enhances punishment resistance in natural reward seeking and impairs place learning in mice. Addict Biol. 2017;22(4):967-76.

22. Abdullah HMA, Haq I, Lamfers R. Cardiac arrest in a young healthy male patient secondary to kratom ingestion: Is this "legal high" substance more dangerous than initially thought? BMJ Case Rep. 2019;12:1-4.

23. Trakulsrichai, Satariya D M, Tongpo, Achara Sc M, Sriapha, Charuwan Sc M Wongvisawakorn, Sunun Sc M, Rittilert, Panee Sc M, Kaojarern, Sming D $\mathrm{M}$, et al. Kratom abuse in ramathibodi poison center, Thailand: A five-year. $J$ Psychoactive Drugs. 2013;45:404-8. 
24. Osborne CS, Overstreet AN, Rockey DC, Schreiner AD. Drug-induced liver injury caused by kratom use as an alternative pain treatment amid an ongoing opioid epidemic. J Investig Med High Impact Case Reports. 2019;7:1-5.

25. Mayangsari A, RostinawatiT. Polimorfisme CYP2D6 dan pengaruhnya terhadap metabolisme Kodein: Review. Farmaka. 2013;14(4):21-34.

26. Rafita ID, Lisdiana, Marianti A. Pengaruh ekstrak kayu manis terhadap gambaran histopatologi dan kadar sgot-sgpt hepar tikus yang diinduksi parasetamol. Life Sci. 2016;4(1):29-37.

27. Stollings JL, Wheeler AP, Rice TW. Incidence and characterization of acute kidney injury after acetaminophen overdose. J Crit Care. 2016;35:191-4.

28. Ghosh J, Das J, Manna P, Sil PC. Acetaminophen induced renal injury via oxidative stress and TNF- $\alpha$ production : Therapeutic potential of arjunolic acid. Toxicology. 2010;268:8-18.

29. Soleimanpour H, Safari S, Nia KS, Sanaie S, Alavian SM. Opioid drugs in patients with liver disease: A systematic review. Hepat Mon. 2016;16(4):1-12.

30. Chikada H, Ida K, Ando E, Inagaki Y, Sakamoto A, Kamiya A. Establishment and analysis of a mouse model that regulates sex- related differences in liver drug metabolism. Lab Investig. 2018;98:1500-11.

31. Madrigal-matute J, Cuervo AM. Reviews in basic and clinical gastroenterology regulation of liver metabolism by autophagy. Gastroenterology. 2016;150:32839.

32. Buraimoh A., Bako I., Ibrahim F. Hepatoprotective effect of ethanolic leave extract of moringa oleifera on the histology of paracetamol induced liver damage in wistar rats. Int Res J Pharm. 2011;3(1):10-3.

33. Domitrović R, Jakovac $H$, Blagojević G. Hepatoprotective activity of berberine is mediated by inhibition of TNF- $\alpha, \mathrm{COX}-2$, and iNOS expression in $\mathrm{CCl} 4$ intoxicated mice. Toxicology. 2011;280:33-43

34. Panjaitan RGP, Masriani. Gangguan fungsi hati induk bunting akibat pemberian tetraklorida. J Kedokt Hewan. 2014;8(2):98-100.

35. Panjaitan RGP, Masriani, Zulfan. Pengaruh pemberian akar pasak bumi (Eurycoma longifolia Jack.) terhadap kerusakan organ hati mencit bunting. J Kedokt Hewan. 2016;10(1):28-31.

36. Panjaitan RGP. Serum enzymes activity and liver histopathological changes of lactating mice treated with Eurycoma longifolia Jack. Roots. Indian J Tradit Knowl. 2017;16(4):593-7.

37. Panjaitan RGP, Manalu W, Handharyani E, Chairul. Aktivitas hepatoprotektor ekstrak metanol akar pasak bumi dan fraksi-fraksi turunannya. Veteriner. 2011;12(4):319-25.

38. Panjaitan RGP, Handharyani E, Chairul, Masriani, Zulfa Z, Manalu W, et al. Pengaruh pemberian tetraklorida terhadap fungsi hati dan ginjal tikus. Makara Kesehat. 2007;11(1):11-6.
39. Harborne JB. Metode Fitokimia: Penuntun Cara Modern Menganalisis Tumbuhan. 2nd ed. Kosasi PN SI, editor. Bandung: ITB Press; 1987.

40. Kiernan JA. Histological \& Histochemical Methods. Theory and Practice. 2nd ed. Canada: Pergamon; 1990. p. 90-97.

41. Diep J, Chin DT, Gupta S, Syed F, Xiong M, Cheng J. Kratom, an emerging drug of abuse. A A Pract. 2018;10(8):192-4.

42. Smith LC, Lin L, Hwang CS, Zhou B, Kubitz DM, Wang $H$, et al. Latera flow assessment and unanticipated toxicity of kratom. Chem Res Toxicol. 2019;32:113-21.

43. Suwanlert S. A Study of Kratom Eaters in Thailand. Bull Narc. 1975;27(3):21-7.

44. Adkins J., E.W B, McCurdy C.R. Mitragyna speciosa, A psychoactive tree from Southeast Asia with opioid activity. Curr Top Med Chem. 2011;11:1165-75.

45. Tatum WO, Hasan TF, Coonan EE, Smelick CP. Recurrent seizures from chronic kratom use, an atypical herbal opioid. Epilepsy Behav Case Reports. 2018;10:18-20.

46. Halpenny GM. Mitragyna speciosa: Balancing potential medical benefits and abuse. ACS Med Chem Lett. 2017;8(9):897-9.

47. Yusoff NHM, Suhaimi FW, Vadivelu RK, Hassan Z, Rümler A, Rotter A, et al Abuse potential and adverse cognitive effects of mitragynine (kratom). Addict Biol. 2016;21(1):98-110.

48. Panjaitan RGP, Manalu W. Hepatoprotective activity of Eurycoma longifolia Jack . roots. Indian J Tradit Knowl. 2013;12(2):225-30.

49. Agarwal R, Agarwal C, Ichikawa H, Singh RP, Aggarwal BB. Anticancer potential of silymarin: From bench to bed side. Anticancer Research. 2006;26:4457-4498.

50. Bahmani M, Shirzad H, Rafieian S, Rafieian-Kopaei M. Silybum marianum: Beyond hepatoprotection. J Evidence-Based Complement Altern Med 2015;20(4):292-301.

51. Vargas-Mendoza N, Madrigal-Santillán E, Morales-González Á, Esquivel-Soto J, Esquivel-Chirino C, García-Luna y González-Rubio MG, et al. Hepatoprotective effect of silymarin. World J Hepatol. 2014;6(3):144-9.

52. Polyak SJ, Morishima C, Lohmann V, Pal S, Lee DYW, Liu Y, et al. Identification of hepatoprotective flavonolignans from silymarin.PNAS. 2010;107(13):5995-9.

53. Jurnalis YD, SayoetiY, Elfitrimelly E. Peran Antioksidan pada Non Alcoholic Fatty Liver Disease (NAFLD). J Kesehat Andalas. 2014;3(1):15-20.

54. Kurniawan IWAY, Wiratmini NI, Sudatri, NW. Histologi hati mencit (Mus musculus L.) yang diberi ekstrak daun lamtoro (Leucaena leucocephala). Simbiosis J Biol Sci. 2014;2(2):226-35

55. Prozialeck WC, Jivan JK, Andurkar S V. Pharmacology of kratom : An emerging botanical agent with stimulant, analgesic and opioid-like effects. JAOA. 2012;112(12):792-9.

56. Raini M. Kratom (Mitragyna speciosa Korth ): manfaat, efek samping dan legalitas. Media Litbankes. 2017;27(3):175-84. 


\section{GRAPHICAL ABSTRACT}

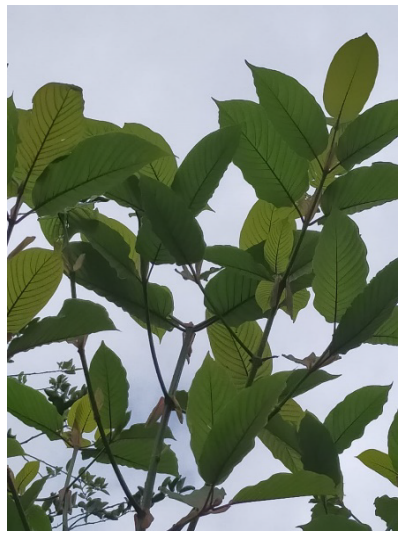

Liver Histopathology

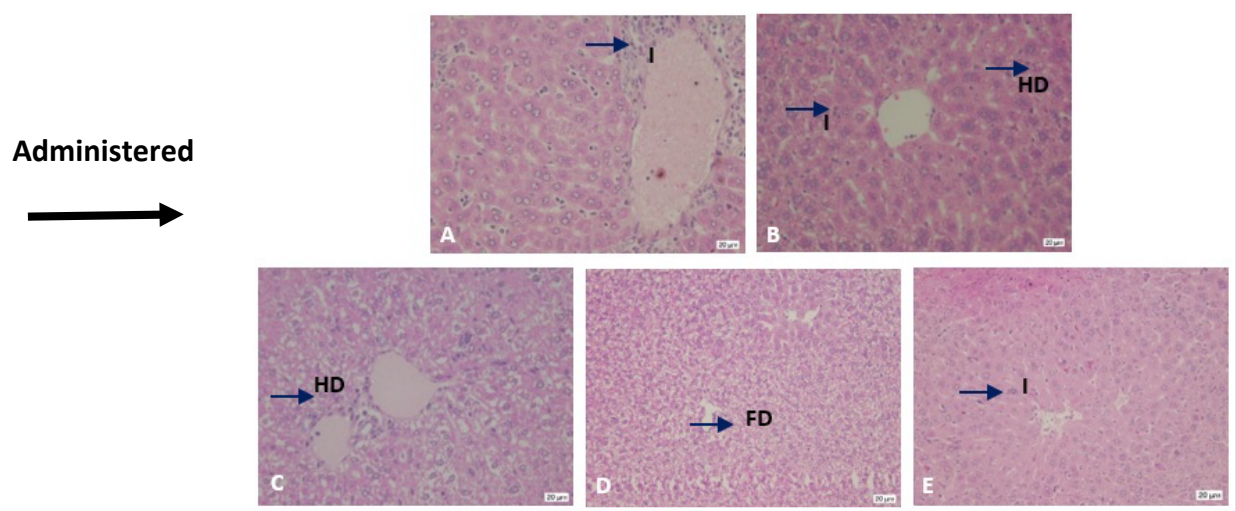

Kratom ((Mitragyna speciosa Korth.)

\section{ABOUT AUTHORS}

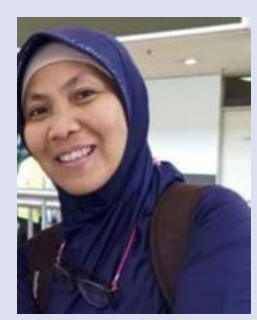

Ruqiah Ganda Putri Panjaitan, graduated from the Department of Biology, FMIPA Andalas University, Padang. She got her masters and doctorates from the Department of Biology FMIPA Bogor Agricultural University. Her field of interest is the study of medicinal plant activity. Now, she is working as a lecturer in Tanjungpura University.

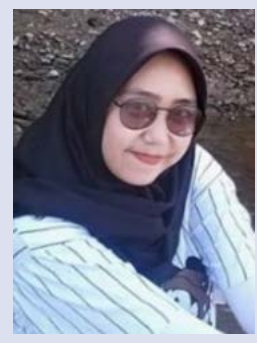

Linda Liridah, completed her bachelor's degree in biology education study program, FKIP, Tanjungpura University, PontianakIndonesia. The title of her thesis is "Developing Documentary Films of Excretion System Material by Giving Kratom Leaf Extract (Mytragyna speciosa Korth) to Mice Liver (Mus musculus)".

Cite this article: Panjaitan RGP, Liridah L. Liver Organ Impairment Due to the Consumption of Kratom Leaves (Mitragyna speciosa Korth.). Pharmacog J. 2021;13(1): 179-84. 